\title{
Influence of Some Thia- or Azasubstituted Butyric Acid Derivatives on the Chemical Shift of the Benzene Ring Carbon Atoms
}

\author{
Johannes Fröhlich $^{1}$, Fritz Sauter ${ }^{1}$ and Viktor Milata ${ }^{2} *$ \\ ${ }^{1}$ Institut for Organic Chemistry, Technical University Wien, Getreidemarkt 9, A-1110 Vienna, Austria \\ E-mail: jfroehli@pop.tuwien.ac.at; fsauter@pop.tuwien.ac.at \\ ${ }^{2}$ Department of Organic Chemistry, Faculty of Chemical Technology, Slovak Technical University, \\ Radlinského 9, SK-812 37 Bratislava, Slovak Republic \\ E-mail:vmilata@cvt.stuba.sk, URL: http://www.chtf.stuba.sk/KATEDRY/koch/milata/viktor.htm \\ * Author to whom correspondence should be addressed.
}

Received: 26 January 2000 / Accepted: 17 March 2000 / Published: 22 March 2000

\begin{abstract}
Eight thia- or azasubstituted butyric acid derivatives were prepared and the influence of these substituents on the chemical shifts of the benzene ring carbon atoms was studied.
\end{abstract}

Keywords: 4-phenyl-3-thiabutyric acid derivatives, 4-phenyl-3-azabutyric acid derivatives, substituent chemical shifts.

\section{Introduction}

For the synthesis of derivatives of (iso)thiochromanone and isoquinolone it was necessary to prepare eight appropriately substituted 4-phenyl-3-(or 4-)thia(or aza)butyric acids and derivatives $\mathbf{1}$. We now report a study of the influence of these substituents on the chemical shifts of the benzene ring carbon atoms of the compounds prepared (Table 1).

(C) 2000 by MDPI (http://www.mdpi.org). Reproduction is permitted for noncommercial purposes. 
Table 1.

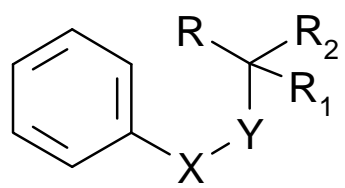

1a-h

\begin{tabular}{cccccccccccc}
\hline No. & $\mathrm{X}$ & $\mathrm{Y}$ & $\mathrm{R}_{1}$ & $\mathrm{R}_{2}$ & $\mathrm{R}$ & $\mathrm{No}$ & $\mathrm{X}$ & $\mathrm{Y}$ & $\mathrm{R}_{1}$ & $\mathrm{R}_{2}$ & $\mathrm{R}$ \\
\hline 1a & $\mathrm{CH}_{2}$ & $\mathrm{~S}$ & $\mathrm{H}$ & $\mathrm{H}$ & $\mathrm{COOH}$ & $\mathbf{1 e}$ & $\mathrm{CH}_{2}$ & $\mathrm{NH}$ & $-\left(\mathrm{CH}_{2}\right)_{4}-$ & $\mathrm{CN}$ \\
$\mathbf{1 b}$ & $\mathrm{S}$ & $\mathrm{CH}_{2}$ & $\mathrm{H}$ & $\mathrm{H}$ & $\mathrm{COOH}$ & $\mathbf{1 f}$ & $\mathrm{CH}_{2}$ & $\mathrm{NH}$ & $-\left(\mathrm{CH}_{2}\right)_{4}-$ & $\mathrm{COOH}$ \\
$\mathbf{1 c}$ & $\mathrm{CH}_{2}$ & $\mathrm{~S}$ & $\mathrm{H}$ & $\mathrm{H}$ & $\mathrm{COOMe}$ & $\mathbf{1 g}$ & $\mathrm{CH}_{2}$ & $\mathrm{NMe}$ & $-\left(\mathrm{CH}_{2}\right)_{4}-$ & $\mathrm{CN}$ \\
$\mathbf{1 d}$ & $\mathrm{S}$ & $\mathrm{CH}_{2}$ & $\mathrm{H}$ & $\mathrm{H}$ & $\mathrm{COOMe}$ & $\mathbf{1 h}$ & $\mathrm{CH}_{2}$ & $\mathrm{NMe}$ & $-\left(\mathrm{CH}_{2}\right)_{4}-$ & $\mathrm{COOH}$ \\
\hline
\end{tabular}

\section{Results and Discussion}

Chemical shifts of all of the compounds studied were assigned on the basis of comparisons between the experimental values acquired from recorded spectra and those calculated using the following programs: ACD / CNMR ver. 1.1 [6], CS Chem Draw Pro, ver. 4.5 [7] and ChemWindow3, ver. 3.0.0 with C13-module [8], respectively. We obtained a good agreement between the measured chemical shifts values and those calculated using all three programs.

Chemical shifts $(\delta)$ and the substituent chemical shift $(\Delta \delta)$ of all of the compounds with heteroatoms in the $\beta$-position are in the same range for all compounds studied. The compounds with the heteroatom in the $\alpha$-position (1b,d) have the ipso-carbon less shifted than the analogues having the heteroatom in the $\beta$-position $(\mathbf{1 a}, \mathbf{1 c}, \mathbf{1 e - 1 h})$. Substituent chemical shifts of meta-carbon atoms of the benzene ring of compounds $\mathbf{1 a}, \mathbf{1 b}$ and $\mathbf{1 d}$ have positive values unlike all the other compounds: 1c, 1e-1h.

The influence of the studied substituents on the chemical shifts of the benzene ring carbon atoms of can be compared, for example with $\mathrm{CH}_{2} \mathrm{SMe}(\mathbf{1 a}, \mathbf{1 c})$, $\mathrm{SMe}(\mathbf{1 b}, \mathbf{1 d})$ or $\mathrm{CH}_{2} \mathrm{NHCHMe}_{2}$, $\mathrm{CH}_{2} \mathrm{NMeCH}_{2} \mathrm{Ph}$ substituents [9] which show good agreement with model compounds (see Table 2). Perhaps $\Delta \delta$ for $\mathrm{C}_{\mathrm{ipso}}$ are slight reduced for all compounds by about $2 \mathrm{ppm}$ and $\mathbf{1 b}, \mathbf{1 d}$ have positive values for $\mathrm{C}_{\text {ortho }}$ in comparison with the compounds bearing the SMe substituents, but this also depends on the solvents used [9]. 
Table 2. Chemical shifts ( $\delta$, in ppm) and substituent chemical shifts $(\Delta \delta)$ of the benzene ring carbon atoms of 4-phenyl-3-(or 4-)thia(or aza)butyric acid derivatives.

\begin{tabular}{|c|c|c|c|c|c|c|}
\hline$-\mathrm{X}-\mathrm{Y}-\mathrm{CR}_{\mathbf{1}} \mathbf{R}_{\mathbf{2}} \mathbf{R}^{*}$ & & $\mathrm{C}_{\mathrm{ipso}}$ & $\mathrm{C}_{\text {orto }}$ & $\mathrm{C}_{\text {meta }}$ & $\mathrm{C}_{\text {para }}$ & Other signals \\
\hline$-\mathrm{CH}_{2}-\mathrm{S}-\mathrm{CH}_{2}-\mathrm{COOH}, \mathbf{1 a}$ & $\delta$ & 136.8 & 129.2 & 128.6 & 127.4 & $176.8,36.3,31.9$ \\
\hline & $\Delta \delta$ & +8.3 & +0.7 & +0.1 & -1.1 & \\
\hline$-\mathrm{S}-\mathrm{CH}_{2} \mathrm{CH}_{2}-\mathrm{COOH}, \mathbf{1 b}$ & $\delta$ & 135.0 & 130.1 & 129.0 & 126.6 & $177.1,34.4,30.9$ \\
\hline & $\Delta \delta$ & +6.5 & +1.6 & +0.5 & -1.9 & \\
\hline$-\mathrm{CH}_{2}-\mathrm{S}-\mathrm{CH}_{2}-\mathrm{COOMe}, \mathbf{1 c}$ & $\delta$ & 137.0 & 128.9 & 128.3 & 127.0 & $170.5,52.0,36.1,31.8$ \\
\hline$-\mathrm{S}-\mathrm{CH}_{2} \mathrm{CH}_{2}-\mathrm{COOMe}, \mathbf{1 d}$ & $\begin{array}{c}\Delta \delta \\
\delta\end{array}$ & $\begin{array}{r}+8.5 \\
135.0\end{array}$ & $\begin{array}{r}+0.4 \\
129.8\end{array}$ & $\begin{array}{r}-0.2 \\
128.8\end{array}$ & $\begin{array}{r}-1.5 \\
126.3\end{array}$ & $171.8,51.5,33.9,28.7$ \\
\hline & $\Delta \delta$ & +6.5 & +1.3 & +0.3 & -2.2 & \\
\hline$-\mathrm{CH}_{2}-\mathrm{NH}-\mathrm{C}\left(\mathrm{CH}_{2}\right)_{4} \mathrm{CN}, \mathbf{1 e}$ & $\delta$ & 139.2 & 128.5 & 128.3 & 127.3 & $122.9,61.2,50.2,39.0,23.5$ \\
\hline & $\Delta \delta$ & +10.7 & 0 & -0.2 & -1.2 & \\
\hline$-\mathrm{CH}_{2}-\mathrm{NH}-\mathrm{C}\left(\mathrm{CH}_{2}\right)_{4} \mathrm{COOH}, \mathbf{1 f}$ & $\delta$ & 140.0 & 128.4 & 127.7 & 127.0 & $179.5,70.0,48.4,35.8,24.2$ \\
\hline & $\Delta \delta$ & +11.5 & -0.1 & -0.8 & -1.5 & \\
\hline$-\mathrm{CH}_{2}-\mathrm{NMe}-\mathrm{C}\left(\mathrm{CH}_{2}\right)_{4} \mathrm{CN}, \mathbf{1 g}$ & $\delta$ & 138.3 & 128.5 & 128.2 & 126.8 & $120.2,68.8,58.4,38.5,37.9,23.2$ \\
\hline \multirow{3}{*}{$-\mathrm{CH}_{2}-\mathrm{NMe}-\mathrm{C}\left(\mathrm{CH}_{2}\right)_{4} \mathrm{COOH}, \mathbf{1 h}^{\mathrm{a}}$} & $\Delta \delta$ & +9.8 & 0 & -0.3 & -1.7 & \\
\hline & $\delta$ & 140.0 & 128.3 & 128.2 & 126.7 & $176.6,74.7,56.7,36.0,32.1,24.8$ \\
\hline & $\Delta \delta$ & +11.5 & -0.2 & -0.3 & -1.8 & \\
\hline
\end{tabular}

$* \delta($ Benzene $)=128.5 \mathrm{ppm}, \delta($ Chloroform $)=77.0 \mathrm{ppm},{ }^{\text {ain }}$ DMSO-d ${ }_{6}, \delta(\mathrm{DMSO})=39.0 \mathrm{ppm}$

\section{Experimental}

\section{General}

The synthesis of thiabutyric acid derivatives was described long ago [1-3] but their ${ }^{13} \mathrm{C}$ NMR spectra have not been published until now. In the case of 3-azabutyronitrile derivatives, the modified Strecker method [4] was applied for the synthesis of the corresponding 2,2-tetramethylene analogs according to the lit. [5]. NMR spectra were determined with a Bruker AC 200 FT-NMR spectrometer and are expressed in ppm downfield from tetramethylsilane (internal standard).

\section{4-Phenyl-3-aza-2,2-tetramethylene butyric acid derivatives $\mathbf{1 e}$ and $\mathbf{1 g}$}

To avoid hydrogen cyanide evolution a solution of potassium cyanide $(30 \mathrm{mmol})$ in water $(10 \mathrm{~mL})$ was slowly added dropwise to a magnetically stirred mixture of benzylamine or N-methylbenzylamine (20 mmol), hydrochloric acid (20 mmol), 25\% ethanol $(40 \mathrm{~mL})$ and cyclopentanone $(20 \mathrm{mmol})$. The mixture was stirred 4 days and the resulting precipitate was filtered off (1e) or the reaction mixture was extracted with ether, dried with sodium sulfate and evaporated (1g). The nitriles were hydrolyzed to the corresponding acids with concentrated sulfuric acid at $20-100^{\circ} \mathrm{C}$ for 12 hours, followed by neu- 
tralization and filtration or extraction, drying and evaporation. 1e: $62 \%$, m.p. $42-43^{\circ} \mathrm{C}$; 1g: $76 \%$, b.p. $130-140^{\circ} \mathrm{C} / 0.45$ Torr.

\section{References and Notes}

1. Petropoulos, J.C.; McCall, M.A.; Tarbel, D.S. J. Amer. Chem. Soc. 1953, 75, 1133.

2. Kiang, A.K.; Mann, F.G. J. Chem. Soc. 1951, 1911.

3. Fong, H.O.; Hardstaff, W.R.; Kay, D.G.; Langler, R.F.; Morse, R.H.; Sandoval, D.-N. Can. J. Chem. 1979, 57, 1206.

4. Strecker, A. Justus Liebigs Ann. Chem. 1850, 75, 27.

5. Euerby, M.R.; Waigh, R.D. J. Chem. Res. (M) 1982, 2417.

6. ACD / CNMR: Advanced Chemistry Development Inc., 141 Adelaide Street West Suite 1501, Toronto, Ontario, M5H 3L5, Canada.

7. CS Chem Draw Pro: CambridgeSoft Corporation, 875 Massachusetts Avenue, Cambridge, MA 02139, USA.

8. ChemWindow 3: SoftShell International, 715 Horizon Dr Suite 390, Grand Junction, CO 81506, USA.

9. Ewing, D.F. Org. Magn. Reson. 1979, 12, 449.

Samples Availability: Not available.

(C) 2000 by MDPI (http://www.mdpi.org). Reproduction is permitted for noncommercial purposes. 